Vol. $50(1-2)-1997$

5-10

\title{
Efficacy of Pseudomonas aeruginosa and other biocontrol agents in the control of root rot infection in cotton
}

\section{SHAMAMA SHAMIM, NUZHAT AHMAD, ATTA-UR-RAHMAN*, S. EHTESHAMUL-HAQUE** AND ABDUL GHAFFAR}

\begin{abstract}
Centre for Molecular Genetics, *HEJ Research Institute of Chemistry, **M.A.H. Qadri Biological Research Centre, University of Karachi, Karachi-75270, Pakistan.
\end{abstract}

(Received 1997)

A b s tract

Seed dressing with Pseudomonas aeruginosa, Paecilomyces lilacinus and Trichoderma koningii significantly $(\mathrm{p}<0.05)$ reduced infection of Macrophomina phaseolina, Rhizoctonia solani and Fusarium solani on cotton roots in pot experiments and in field. Combined use of P.aeruginosa strain CMG63 with T. koningii produced greater plant height and fresh weight of shoot in field as compared to CMG52 which showed better results in pot experiments.

Key words: Pseudomonas aeruginosa, Biocontrol agents, Cotton root rot.

\section{INTRODUCTION}

Soilborne root infecting fungi attack roots of plant, limit nutrient uptake by plant and produce root rot disease complex resulting in the death of plants. Of the disease causing organisms, M. phaseolina is widely distributed in tropical and subtropical countries of the world is known to cause seedling blight, charcoal rot, root rot, stem rot, pod rot on more than 500 species of plants with 64 hosts recorded from Pakistan (Dhingra \& Sinclair, 1978; Sinclair, 1982; Ghaffar, 1988; Ehteshamul-Haque and Ghaffar, 1994). Of the species of Fusarium, $F$. oxysporum and $F$. solani are very common in agricultural fields of Pakistan and cause root rot, stem rot and wilt diseases on a wide range of plants (B o o th, 1971; Eh te s h a m u l- H a que and G h a f f a r, 1994). Similarly $R$. solani which is known to produce seed rot, damping off of seedlings, wilt and root rot on over 2000 species of plants (P a rmeter, 1970) has been reported from atleast 68 hosts in Pakistan (Ghaffar, 1988; Ehteshamul-Haque and Ghaffar, 1994). 
Many species of Pseudomonas promote plant growth and also reduce the population of deleterious rhizospheric fungi and bacteria ( $\mathrm{c} \mathrm{ch} \mathrm{roth}, \mathrm{H}$ a n c o c k, 1981; W e lle r, 1988). Among the fluorescent $P$ seudomonas some strains of $P$. aeruginos $a$ were found to enhance the growth of many crops like soybean, sunflower, wheat, mashbean and chickpea (E h t e s h a m u l-H a q u e, 1996) and also inhibited the growth of root rot pathogens viz., Macrophomina phaseolina, Rhizoctonia solani and Fusarium spp., ( $\mathrm{S} \mathrm{h}$ a $\mathrm{m}$ i $\mathrm{m}$ et al., 1994). Application of these bacteria significantly reduced root rot disease in chickpea (I zhar et al., 1995). Duffy and Weller (1992), reported better control of take-all disease of wheat where Trichoderma koningii was used with Pseudomonas fluorescens than their separate use. Combined use of Bradyrhizobium japonicum with Trichoderma spp., showed better control of root infecting fungi in soybean than their separate use (Ehteshamul-Haque and Ghaffar, 1995). In the present study some strains of Pseudomonas aeruginosa were used with or without Paecilomyces lilacinus and T. koningii in the control of root rot disease of cotton caused by M. phaseolina, $R$. solani and Fusarium spp.

\section{MATERIALS AND METHODS}

Five day old cultures of Pseudomonas aeruginosa strain CMG63, CMG52 and CMG58 grown on Nutrient agar medium whereas $T$. koningii and $P$. lilacinus on Potato Dextrose Agar were used. A cell suspension of CMG63 @6x108 $\mathrm{cfu} \mathrm{ml}^{-1}$, CMG52@

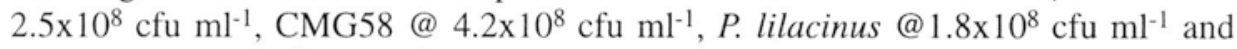

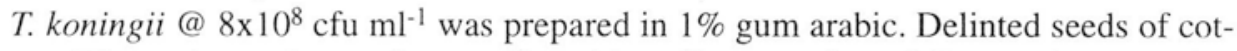
ton (Gossypium arboreum) were dipped in cell suspension of $P$. aeruginosa strains CMG63, CMG52 and CMG58 used alone or mixed with P. lilacinus and T. koningii. After treatment with microbial suspension seeds were sown in $8 \mathrm{~cm}$ diam., plastic pots, containing $250 \mathrm{~g}$ soil @ 8 seeds per pot. There were 4 replicates of each treatment. The pots were randomized on a screen house bench at the M.A.H. Qadri Biological Research Centre, University of Karachi and kept at 50\% Water Holding Capacity (K e e n, R a c z k ow s k i, 1921). In a separate set seeds were sown in rows of $2 \times 1$ meter microplots at the Department of Botany, University of Karachi in randomized complete block design. There were 3 replicates of each treatments. The soil had a natural infestation of 3-10 sclerotia of $M$. phaseolina $\mathrm{g}^{-1}$ of soil as found by wet sieving and dilution technique ( $\mathrm{Sh}$ e i kh, Ghaff a r, 1975), 8\% colonization of $R$. solani on sorghum seeds used as baits (W i $1 \mathrm{~h} \mathrm{e} 1 \mathrm{~m}, 1955$ ) and $3500 \mathrm{cfu} \mathrm{g}^{-1}$ of soil of a mixed population of $F$. oxysporum and $F$. solani as assessed by soil dilution technique (N a s h, S n y d e r, 1962).

Plants were uprooted after 6 weeks growth and after washing with running tap water, 5 one $\mathrm{cm}$ long root pieces from each plant were cut, surface sterilized with $1 \% \mathrm{Ca}(\mathrm{OCl})_{2}$ for 3 minutes and transferred onto PDA plates containing penicillin (100000 units/ litre) and streptomycin $(0.2 \mathrm{gm} / \mathrm{litre})$. After incubation for 5 days at $28^{\circ} \mathrm{C}$, the incidence of root infecting fungi viz., M. phaseolina, R. solani and Fusarium spp., were recorded using the formula: 


$$
\text { Infection } \%=\frac{\text { Total no. of plants infected by a pathogen }}{\text { Total number of plants }} \times 100
$$

Fresh weight and length of shoots were also recorded. Data were analysed and subjected to Factorial ANOVA (FANOVA) followed by least significant differences (LSD) according to Gomez and Gomez (1984).

\section{RESULTS \\ Pot experiment}

P. aeruginosa strains CMG63, CMG52 and CMG58, P. lilacinus and T. koningii significantly $(\mathrm{p}<0.05)$ reduced infection of $M$. phaseolina when used alone or where $P$. aeruginosa was used with $P$. lilacinus and $T$. koningii (Table 1). Complete control of $R$. solani was observed where $P$. aeruginosa strains CMG63, CMG58 and $P$. lilacinus were used alone or CMG63 was used with $P$. lilacinus. Use of strain CMG52 and $T$. koningii also significantly $(\mathrm{p}<0.05)$ reduced $R$. solani infection. Complete control of $F$. solani infection was obtained where CMG58 was used alone or where CMG58 or CMG52 were used with T. koningii. CMG63 and P. lilacinus also significantly $(\mathrm{p}<0.05)$ controlled infection of $F$. solani on cotton roots (Table 1). Greater plant height was observed where T. koningii was used with CMG52. Combined use of T. koningii with CMG58 resulted in maximum fresh weight of shoot (Table 1).

Field experiment

More than 50\% control of $M$. phaseolina infection was observed where $P$. aeruginosa strain CMG63, CMG58, P. lilacinus were used alone or where $P$. lilacinus was used with CMG63, CMG58 or CMG52 and T. koningii used with CMG63 and CMG52 (Table 1). Complete control of $R$. solani infection was observed where CMG63 was used alone or where $P$. lilacinus was used with CMG63 or CMG52 and T. koningii used with CMG63 or CMG58. Complete control of $F$. solani infection was found in treatments where $P$. lilacinus was used alone or with $P$. aeruginosa strains (Table 1). Maximum plant height was observed where CMG63 was used alone or with T. koningii. Greater fresh weight of shoot was produced by CMG52 with $T$. koningii followed by P. lilacinus used with CMG63 or CMG58 (Table 1).

\section{DISCUSSION}

In the presented study, strains of $P$. aeruginosa gave significant $(\mathrm{p}<0.05)$ results in controlling the infection of $M$. phaseolina, $R$. solani and $F$. solani on cotton. Among the fluorescent Pseudomonas, $P$. fluorescens is known to reduce infection of many 
Table $1-$ Tabela 1

Effect of different strains of Pseudomonas aeruginosa, Paecilomyces lilacinus and Trichoderma koningii in the control of root infecting fungi and growth of cotton plant.

\begin{tabular}{|c|c|c|c|c|c|c|}
\hline No. & Treatments & M.phaseolina & R. solani & F. solani & $\begin{array}{l}\text { Plant height } \\
(\mathrm{cm})\end{array}$ & $\begin{array}{l}\text { Fresh weight } \\
(\mathrm{g})\end{array}$ \\
\hline \multicolumn{7}{|c|}{ POTS EXPERIMENT } \\
\hline 1. & Control & 47 & 64 & 39 & 10.1 & 1.4 \\
\hline 2. & P.aeruginosa (CMG63) & 21 & 0 & 12 & 9.6 & 1.2 \\
\hline 3. & P.aeruginosa (CMG52) & 23 & 12 & 14 & 9.8 & 1.5 \\
\hline 4. & Paeruginosa (CMG58) & 33 & 0 & 0 & 12.4 & 2.4 \\
\hline 5. & P.lilacinus (PL) & 16 & 0 & 6 & 10.6 & 1.3 \\
\hline & T.koningii (TK) & 14 & 14 & 37 & 10.1 & 1.2 \\
\hline & $\mathrm{PL}+63$ & 21 & 0 & 27 & 9.4 & 1.5 \\
\hline & $\mathrm{PL}+52$ & 21 & 6 & 25 & 10.6 & 1.3 \\
\hline & $\mathrm{PL}+58$ & 23 & 21 & 6 & 9.4 & 1.0 \\
\hline 10. & $\mathrm{TK}+63$ & 12 & 8 & 14 & 11.6 & 2.0 \\
\hline 11. & $\mathrm{TK}+52$ & 14 & 14 & 0 & 12.5 & 1.7 \\
\hline & $\mathrm{TK}+58$ & 14 & 12 & 0 & 11.4 & 2.2 \\
\hline & & \multicolumn{3}{|c|}{$\begin{array}{c}\mathrm{LSD}_{0.05} \text { (Treatments) }=14.3 \\
\text { (Pathogens) }=7.1\end{array}$} & 2.3 & 0.61 \\
\hline \multicolumn{7}{|c|}{ FIELD EXPERIMENT } \\
\hline & Control & 58 & 11 & 19 & 19.1 & 2.1 \\
\hline 2. & P.aeruginosa (CMG63) & 8 & 0 & 8 & 25.5 & 2.6 \\
\hline 3. & P.aeruginosa (CMG52) & 41 & 41 & 11 & 23.1 & 2.5 \\
\hline & P.aeruginosa (CMG58) & 6 & 11 & 8 & 24.4 & 1.7 \\
\hline & P.lilacinus (PL) & 19 & 19 & 0 & 24.4 & 1.7 \\
\hline & T.koningii (TK) & 50 & 16 & 8 & 24.1 & 2.2 \\
\hline & $\mathrm{PL}+63$ & 25 & 0 & 0 & 24.9 & 3.1 \\
\hline & $\mathrm{PL}+52$ & 19 & 0 & 0 & 23.5 & 2.7 \\
\hline & $\mathrm{PL}+58$ & 19 & 27 & 0 & 25.6 & 3.1 \\
\hline & $\mathrm{TK}+63$ & 11 & 0 & 11 & 21.6 & 1.5 \\
\hline & $\mathrm{TK}+52$ & 25 & 19 & 19 & 23.3 & 3.3 \\
\hline \multirow{2}{*}{\multicolumn{2}{|c|}{ 12. $\mathrm{TK}+58$}} & 33 & 0 & 8 & 23.4 & 2.7 \\
\hline & & \multicolumn{3}{|c|}{$\begin{array}{c}\text { LSD }_{0.05}(\text { Treatments })=15.4 \\
\text { (Pathogens) }=7.7\end{array}$} & 3.9 & 0.92 \\
\hline
\end{tabular}

pathogens including $F$. oxysporum in banana ( $\mathrm{S}$ i v a m a n i, G $\mathrm{n}$ a n a m a $\mathrm{n} \mathrm{i} \mathrm{kam}$, 1988) and Verticillium dahliae on potato (L e be n et al., 1987). P. aeruginosa has also been reported to reduce growth of $R$. solani, Sclerotium rolfsii and $F$. solani (P o dil e et al., 1988). It is interesting to note that different strains of $P$. aeruginosa showed variability against different pathogens. Presumably like rhizobia $(\mathrm{Ch}$ a o, 1990), the antagonistic ability of $P$. aeruginosa also varies with strains. Since use of some strain of $P$. aeruginosa with $P$. lilacinus or $T$. koningii showed better control of $F$. solani than either used alone. A better control of Gaeumannomyces graminis var. tritici was observed by $T$. koningii when used with fluorescent Pseudomonas (D u ff y, We 11 e r, 1992). Use of rhizobia with Trichoderma spp., have given better results in the control of root rot pathogens on fenugreek as compared to their separate use 
(Ehteshamul-Haque, Ghaffar, 1992). Combined use of T. koningii with $P$. aeruginosa also showed an increase in plant height and better fresh weight of shoot as compared to their separate use. In the rhizosphere, population of bacteria and fungi may avoid competition by colonizing different niches and or by some degree of spatial separation within the rhizosphere. Combination of compatible bacteria and fungi may therefore provide better control of seed and root rot pathogens than either used alone (Ch a o et al., 1986).

\section{REFERENCES}

B o ot h, C. 1971. The genus Fusarium. Commonwealth Mycological Institute, Kew, Surrey, England. pp. 237. Ch a o W. L., 1990. Antagonistic activity of Rhizobium spp., against beneficial and plant pathogenic fungi. Letters in Applied Microbiology 10: 213-215.

Ch a o W. L., Nelson E. B., Harman G. E., Hoch H. C., 1986. Colonization of the rhizosphere by biocontrol agents applied to seeds. Phytopathology 76: 60-65.

D h i n g r a, O. D. and J. B. S i n c l a i r. 1978. Biology and Pathology of Macrophomina phaseolina. Imprensa Universitaria, Universidade Federal Devicosa, Vicosa-Minas Gerais-Brasil. pp. 166.

D u f f y, B. K., Welle r M., 1992, Suppression of take all by Trichoderma koningii used individually and in combination with fluorescent Pseudomonas spp. Phytopathology 82: 1080.

Ehte s ha mul- H a que, S. 1996. Use of plant growth promoting bacteria in the biological control of soilborne root infecting fungi. 2nd Annual Research Report. PAEC, Islamabad. M.A.H. Qadri Biological Research Centre, Univerity of Karachi, Karachi-75270, Pakistan. pp. 103.

Ehte shamul-Haque, S. and A. G h a f far. 1994. New records of root infecting fungi from Pakistan. Pak. J. Phytopath., 6: 50-57.

Ehteshamul-Haque S., Ghaff ar A., 1992. Efficacy of Trichoderma spp., and Rhizobium meliloti in the control of root rot of fenugreek. Pak. J. Bot. 24: 217-221.

Ehteshamul-Haque S., Ghaff a r A., 1995. Role of Bradyrhizobium japonicum and Trichoderma spp. in the control of root rot disease of soybean. Acta Mycologica 30: 35-40.

$\mathrm{G}$ h a f f a r, A. 1988. Soilborne Diseases Research Centre. Final Research Report. Department of Botany, University of Karachi, Karachi-75270. Pakistan, pp.111.

Gomez K. A., Gome z, A. A., 1984. Statistical procedures for agricultural research. 2 nd ed. Wiley, New York. pp. 680 .

Izhar I., Ehteshamul-Haque S., Javeed M., Ghaffar A., 1995. Efficacy of Pseudomonas aeruginosa and Bradyrhizobium sp., in the control of root rot disease in chickpea. Pak.J.Bot. 27: 451-455.

Keen B. A., R a c zkow ski H., 1921. The relationship between clay content and certain physical properties of soil. J. Agric. Sci. 11: 441-449. Leben S.D., Wadi J.A., Easton G.D. 1987. Effects of Pseudomonas fluorescens on potato plant growth and control of Verticillium dahliae. Phytopathology 77: 1592-1595.

N a s h S. M., S n y der W. C., 1962. Quantitative estimations by plate counts of propagules of the bean root rot Fusarium in field soils. Phytopathology 52: 567-572.

Parmeter J. R. 1970. Rhizoctonia solani, Biology and pathology, University of California Press, Berkeley, Los Angeles and London. pp. 255.

Podile A. R., Kum ar B.S. D., Dube H. C., 1988. Antibiosis of rhizobacteria against some plant pathogens. Indian J. Microbiol., 28: 108-111.

S chroth M. N., H a n c ock J., 1981. Selected topics in biological control. Annu. Rev. Microbiol. 35: 453-476.

Shamim S., Ahmad N., Atta-ur-Rahman, Ehteshamul-Haque S. Ghaffar A., 1994. Isolation and characterization of soil bacteria showing antifungal activity against phytopathogens. In: Recent trends in biochemical research in Pakistan. R. Qasim, S. N. Hasnain, M. Ishaq and A. Azhar (eds.). Department of Biochemistry, University of Karachi, Karachi-75270, Pakistan. pp. 329-337.

Sheikh A. H., Ghaffar A., 1975. Population study of sclerotia of Macrophomina phaseolina in cotton fields. Pak. J. Bot. 7: 13-17.

S i n cl a i r, J. B. 1982. Compendium of soybean diseases. 2nd ed. Amer. Phytopath. Soc. St. Paul, Minnesota. pp. 104. 
S i va ma n i E., G n a n a m a n i ck a m S. S., 1988. Biological control of Fusarium oxysporum f.sp. cubense in banana by inoculation with Pseudomonas fluorescens. Plant \& Soil 107: 3-9.

Weller, D. M., 1988. Biological control of soilborne plant pathogens in the rhizosphere with bacteria. Ann. Rev. Phytopathol. 26: 379-407.

Wil he I m S., 1955. Longevity of the Verticillium wilt fungus in the laboratory and field. Phytopathology 45: 180-181.

\title{
Skuteczność Pseudomonas aeruginosa i innych preparatów biologicznych w kontroli zgnilizny korzeni bawełny
}

\author{
Streszczenie
}

Zastosowanie Pseudomonas aeruginosa, Paecilomyces Lilaciunus i Trichoderma koningii znacznie $(\mathrm{p}<0.05)$ zmniejszyło występowanie zakażenia korzeni bawełny bakteriami Macrophomina phaseolina, Rhizoctonia solani i Fusarium solani, zarówno w eksperymentach polowych jak i doniczkowych. Wspólne zastosowanie $P$. aeruginosa, szczep CMG63 i $T$. koningii w eksperymentacyh polowych sprawiło większy przyrost roślin i świeżej masy pędów, zaś zastosowanie szczepu CMG52 dało lepsze rezultaty w eksperymentach doniczkowych.

Pojęcia kluczowe: Pseudomonas aeruginosa, preparaty biologiczne, zgnilizna korzeni bawełny. 